\title{
DETERMINAN KEJADIAN ANEMIA GIZI BESI PADA IBU HAMIL KURANG ENERGI KRONIS DI WILAYAH KERJA PUSKESMAS SUMBERJAMBE KABUPATEN JEMBER
}

\section{The Determinants of Iron Deficiency Anemia Incidence in Pregnant Women with Chronic Energy Deficiency at Sumberjambe Working Area Primary Health Center Jember Regency}

\author{
Leilya Irwanti*, Sulistiyani, Ninna Rohmawati \\ Peminatan Gizi Kesehatan Masyarakat Fakultas Kesehatan Masyarakat Universitas Jember \\ *e-mail: leilyairwanti@gmail.com
}

\begin{abstract}
The iron deficiency anemia is a condition caused by a lack of nutrients that an important role in the formation of hemoglobin, it is happened due to the lack of consumption and due to absorption disorders. One of the factors associated with iron deficiency anemia in pregnant women is chronic energy deficiency. This study aimed to examine the determinants of the incidence iron deficiency anemia in pregnant women with chronic energy deficiency in the working area of Sumberjambe Primary Health Center in Jember Regency. This research was a descriptive study. The determination of the sample in this study used a total sampling technique, there were 44 research subjects of pregnant women with chronic energy deficiency. The researcher collected the data by using interview methods, knowledge tests, and hemoglobin measurements of pregnant women. The results of the study show that most of pregnant women were in the young age group (20 years below), they had basic education level, unemployed, the family income is below the regional minimum wage of Jember, and had sufficient knowledge, had a low parity, low birth gap, ANC meets K4, most of their carbohydrates, proteins and fats consumption tend to be high. Meanwhile, the iron consumption was in the deficit category. In the consumption pattern of iron inhibitors, most of them never consume tea, coffee, potatoes and they often consume long beans and cucumbers.
\end{abstract}

Keywords: Iron deficiency anemia, chronic energy deficiency, pregnant women

\begin{abstract}
Abstrak
Anemia gizi besi adalah suatu keadaan yang disebabkan oleh kekurangan zat gizi yang berperan dalam pembentukan hemoglobin, baik karena kekurangan konsumsi maupun karena gangguan absorbsi. Salah satu faktor yang berhubungan dengan anemia gizi besi pada ibu hamil adalah kekurangan energi kronis (KEK). Tujuan dari penelitian ini untuk mengkaji determinan kejadian anemia gizi besi pada ibu hamil KEK di wilayah kerja Puskesmas Sumberjambe Kabupaten Jember. Penelitian ini merupakan penelitian deskriptif. Penentuan sampel dalam penelitian ini menggunakan teknik total sampling yaitu sebanyak 44 ibu hamil KEK. Peneliti mengumpulkan data menggunakan metode wawancara, tes pengetahuan, dan pengukuran $\mathrm{Hb}$ ibu hamil. Hasil penelitian menunjukkan sebagian besar ibu hamil berada pada kelompok umur muda ( $<20$ tahun), tingkat pendidikan dasar, tidak bekerja, pendapatan keluarga dibawah UMK, serta memiliki pengetahuan cukup, paritas rendah, jarak kelahiran rendah, pemeriksaan kehamilan ANC memenuhi K4, tingkat konsumsi karbohidrat, protein dan lemak dalam kategori lebih. Sedangkan, konsumsi zat besi dan zat enhancer Fe dalam kategori defisit, konsumsi zat inhibitor Fe yaitu tidak pernah mengonsumsi teh, kopi, kentang dan sering mengonsumsi kacang panjang dan ketimun.
\end{abstract}

Kata Kunci: Anemia gizi besi, kurang energi kronis, ibu hamil 


\section{PENDAHULUAN}

Anemia karena defisiensi zat besi merupakan penyebab utama anemia pada ibu hamil. Anemia jenis ini merupakan salah satu gangguan yang paling sering terjadi selama kehamilan di mana ibu hamil mengalami deplesi besi sehingga hanya memberi sedikit besi kepada janin untuk metabolisme besi yang normal. Berdasarkan daftar yang dirilis oleh WHO, prevalensi anemia gizi secara global sejak tahun 1993-2005 pada ibu hamil adalah $41,8 \%$ dengan populasi yang terkena adalah 56 juta (Citrakesumasari, 2012). Hasil Survei Riset Kesehatan Dasar (Riskesdas) tahun 2007 dan 2013 diketahui bahwa prevalensi anemia gizi besi pada ibu hamil menurun dari 59\% tahun 2007 menjadi 37,1\% tahun 2013 (Depkes RI, 2007 dan Kemenkes RI, 2013a). Angka ini masih termasuk dalam kategori tinggi (standar WHO; 5-9\% rendah, 10-19\% sedang, 20-39\% tinggi, > 40\% sangat tinggi). Prevalensi anemia di Jawa Timur sangat tinggi yaitu $49,9 \%^{6}$, namun di Kabupaten Jember prevalensi anemia mengalami penurunan dari $11,47 \%$ tahun 2016 menjadi $10,42 \%$ tahun 2017. Prevalensi anemia gizi besi pada ibu hamil tahun 2015 di Puskesmas Sumberjambe sebesar $81,70 \%$ dan merupakan wilayah terbesar untuk kasus anemia ibu hamil di Kabupaten Jember, sedangkan tahun 2017 tercatat $11,03 \%$ kasus anemia pada ibu hamil. Kejadian anemia ini termasuk dalam kategori mild public health problem (CDC and Prevention, 2005).

Ibu hamil cenderung terkena anemia pada tiga bulan terakhir kehamilannya, karena pada masa ini terjadi ekspansi jaringan ibu dan pembentukan sel-sel darah merah janin, serta janin akan menimbun cadangan zat besi untuk dirinya sendiri sebagai persediaan bulan pertama sesudah lahir (Maulana, 2007).

Beberapa faktor yang mempengaruhi terjadinya anemia defisiensi besi pada ibu hamil, antara lain karakteristik ibu, status kesehatan ibu, tingkat konsumsi ibu, dan lingkungan. Faktor karakteristik ibu hamil meliputi umur ibu, tingkat pendidikan, status pekerjaan, tingkat pendapatan keluarga dan tingkat pengetahuan. Faktor status kesehatan meliputi paritas, jarak kelahiran dan pemeriksaan kehamilan (Antenatal Carel ANC). Gizi dipengaruhi oleh faktor langsung dan faktor tidak langsung (Soekirman, 2004). Faktor langsung meliputi penyakit infeksi dan asupan makanan. Sedangkan faktor tidak langsung meliputi persediaan pangan keluarga, pendidikan dan pengetahuan ibu, pendapatan, sanitasi lingkungan dan pelayanan kesehatan. Hal lain yang berkaitan dengan kejadian anemia pada ibu hamil yaitu umur ibu, paritas, pendidikan, pekerjaan dan jarak kelahiran (Rochjiati, 2013).

Salah satu faktor yang berhubungan dengan anemia gizi besi pada ibu hamil adalah KekuranganEnergi Kronis (KEK) dalam kehamilan. Berdasarkan hasil Riskesdas 2007 dan 2013 diketahui bahwa prevalensi wanita hamil dengan KEK di Indonesia meningkat dari tahun 2007 hingga 2013 (Depkes RI 2007 dan 2009b) sedangkan prevalensi di Kabupaten Jember menurun dari 10,69\% tahun 2016 menjadi 9,39\% tahun 2017. Kejadian KEK di Desa Sumberjambe pada tahun 2017 sebesar 10,35\% dan menempati posisi 10 besar daerah dengan kasus KEK terbanyak pada ibu hamil. KEK dan anemia dalam kehamilan merupakan masalah kesehatan di Indonesia.

Kurang energi kronis dan anemia dalam kehamilan berkaitan dengan asupan gizi yang kurang optimal selama kehamilan yang berperan penting bagi tumbuh kembang janin. Kondisi kesehatan ibu selama kehamilan diperparah oleh kejadian anemia yang dapat membawa pengaruh buruk terhadap kesehatan ibu maupun janinnya, baik dalam kehamilan, persalinan maupun nifas, yang dapat meningkatkan morbiditas maupun mortalitas ibu dan anak.

Berkaitan dengan keadaan tersebut maka perlu dilakukan penelitian untuk mengkaji determinan kejadian anemia gizi besi pada ibu hamil kurang energi kronis di wilayah kerja Puskesmas Sumberjambe Kabupaten Jember sehingga dapat dijadikan dasar untuk perbaikan status kesehatan ibu dan anak.

\section{METODE PENELITIAN}

Penelitian ini dilakukan dengan menggunakan jenis penelitian deskriptif. Populasi dalam penelitian ini adalah ibu hamil yang berada di wilayah kerja Puskesmas Sumberjambe Kabupaten Jember sebanyak 44 ibu hamil KEK yang ditentukan menggunakan teknik total sampling. Peneliti mengumpulkan data menggunakan metode wawancara dan tes pengetahuan menggunakan lembar angket atau kuesioner responden, formulir food recall $2 \times 24$ hours dan formulir frekuensi makanan, dan pengukuran $\mathrm{Hb}$ ibu hamil yang diukur dengan 
alat Easy Touch GCHb. Teknik analisis data dalam bentuk deskriptif dan disajikan dalam bentuk frekuensi dan tabulasi silang.

\section{HASIL DAN PEMBAHASAN}

\section{Hasil}

Status Anemia Gizi Besi Responden

Berdasarkan Tabel 1 didapatkan bahwa sebagian besar ibu hamil di Puskesmas Sumberjambe menderita anemia berdasarkan hasil tes kadar $\mathrm{Hb}$ darah sebanyak 28 orang responden $(63,64 \%)$, sedangkan sisanya sebanyak 16 orang responden $(36,36 \%)$ tidak menderita anemia.

Tabel 1. Distribusi Frekuensi Status Anemia Gizi Besi Responden di Wilayah Kerja Puskesmas Sumberjambe Tahun 2017

\begin{tabular}{lcc}
\hline Status Anemia & $\begin{array}{c}\text { Jumlah } \\
(\mathbf{n})\end{array}$ & $\begin{array}{c}\text { Persentase } \\
(\boldsymbol{\%})\end{array}$ \\
\hline Anemia & 28 & 63,64 \\
Tidak Anemia & 16 & 36,36 \\
\hline
\end{tabular}

\section{Karakteristik Responden}

Berdasarkan Tabel 2 diketahui dari 44 responden yang diteliti, sebagian besar umur ibu berada pada kategori muda ( $<20$ tahun) dengan persentase $52,27 \%$. Tingkat pendidikan ibu sebagian besar berada kategori dasar dengan persentase 52,27\%. Tingkat pengetahuan ibu berada pada kategori cukup dengan persentase $54,55 \%$. Sebagian besar ibu tidak bekerja dengan persentase 93,18\% dan tingkat pendapatan keluarga berada pada kategori dibawah UMK Kabupaten Jember dengan persentase $65,91 \%$.

Tabel 2. Distribusi Frekuensi Karakteristik Responden berdasarkan Umur, Tingkat Pendidikan, Status Pekerjaan, Tingkat Pendapatan dan Tingkat Pengetahuan Ibu Hamil di Wilayah Kerja Puskesmas Sumberjambe Tahun 2017

\begin{tabular}{lcccccc}
\hline \multirow{2}{*}{$\begin{array}{l}\text { Karakteristik } \\
\text { Responden }\end{array}$} & \multicolumn{4}{c}{ Status Anemia } & \multirow{2}{*}{ Jumlah } \\
\cline { 2 - 6 } & \multicolumn{2}{c}{ Anemia } & \multicolumn{1}{c}{ Tidak } & & \\
\cline { 2 - 6 } & $\mathbf{n}$ & $\mathbf{\%}$ & $\mathbf{n}$ & $\mathbf{\%}$ & $\mathbf{n}$ & $\mathbf{\%}$ \\
\hline 1.Umur ibu & & & & & \\
Muda & 12 & 27,27 & 11 & 25,00 & 23 & 52,27 \\
Produktif & 14 & 31,82 & 5 & 11,36 & 19 & 43,18 \\
Risiko tinggi & 2 & 4,55 & 0 & 0 & 2 & 4,55 \\
2. Tingkat pendidikan & & & & \\
Dasar & 13 & 29,55 & 10 & 22,73 & 23 & 52,27 \\
Menengah & 15 & 34,09 & 5 & 11,36 & 20 & 45,45 \\
Tinggi & 0 & 0 & 1 & 2,27 & 1 & 2,27 \\
\hline
\end{tabular}

Tabel 2. Distribusi Frekuensi Karakteristik Responden berdasarkan Umur, Tingkat Pendidikan, Status Pekerjaan, Tingkat Pendapatan dan Tingkat Pengetahuan Ibu Hamil di Wilayah Kerja Puskesmas Sumberjambe Tahun 2017 (lanjutan)

\begin{tabular}{|c|c|c|c|c|c|c|}
\hline \multirow{3}{*}{$\begin{array}{c}\text { Karakteristik } \\
\text { Responden }\end{array}$} & \multicolumn{4}{|c|}{ Status Anemia } & \multirow{2}{*}{\multicolumn{2}{|c|}{ Jumlah }} \\
\hline & \multicolumn{2}{|c|}{ Anemia } & \multicolumn{2}{|c|}{ Tidak } & & \\
\hline & $\mathbf{n}$ & $\%$ & $\mathbf{n}$ & $\%$ & $\mathbf{n}$ & $\%$ \\
\hline \multicolumn{7}{|c|}{ 3. Status Pekerjaan } \\
\hline Bekerja & 2 & 4,55 & 1 & 2,27 & 3 & 6,82 \\
\hline Tidak bekerja & 26 & 59,09 & 15 & 34,09 & 41 & 93,18 \\
\hline \multicolumn{7}{|c|}{ 4. Pendapatan keluarga } \\
\hline$\geq \mathrm{UMK}$ & 10 & 22,73 & 5 & 11,36 & 15 & 34,09 \\
\hline$<$ UMK & 18 & 40,91 & 11 & 25,00 & 29 & 65,91 \\
\hline \multicolumn{7}{|c|}{ 5. Tingkat pengetahuan } \\
\hline Baik & 1 & 2,27 & 2 & 4,55 & 3 & 6,82 \\
\hline Cukup & 16 & 36,36 & 8 & 18,18 & 24 & 54,55 \\
\hline Kurang & 11 & 25,00 & 6 & 13,64 & 17 & 38,64 \\
\hline
\end{tabular}

\section{Status Kesehatan Responden}

Berdasarkan Tabel 3 diketahui dari 44 responden yang diteliti paritas ibu berada pada kategori rendah dengan persentase $100 \%$. Sebagian besar jarak kelahiran antar anak berada pada kategori risiko rendah dengan persentase $88,64 \%$. Pemeriksaan kehamilan (Antenatal Carel ANC) pada sebagian besar ibu hamil memenuhi K4 berdasarkan trimesternya dengan persentase $93,18 \%$.

Tabel 3. Distribusi Frekuensi Status Kesehatan Berdasarkan Paritas, Jarak Kelahiran dan Pemeriksaan Kehamilan (Antenatal Carel ANC) di Wilayah Kerja Puskesmas Sumberjambe Tahun 2017

\begin{tabular}{|c|c|c|c|c|c|c|}
\hline \multirow{2}{*}{$\begin{array}{c}\text { Status } \\
\text { Kesehatan }\end{array}$} & \multicolumn{4}{|c|}{ Status Anemia } & \multicolumn{2}{|c|}{ Jumlah } \\
\hline & & emia & & idak & & \\
\hline & 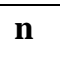 & $\%$ & $\mathbf{n}$ & $\%$ & $\mathbf{n}$ & $\%$ \\
\hline \multicolumn{7}{|l|}{ 1. Paritas } \\
\hline Rendah & 28 & 63,64 & 16 & 36,36 & 44 & 100,00 \\
\hline Tinggi & 0 & 0 & 0 & 0 & 0 & 0 \\
\hline \multicolumn{7}{|c|}{ 2. Jarak Kelahiran } \\
\hline Risiko & 24 & 54,55 & 15 & 34,09 & 39 & 88,64 \\
\hline Risiko tinggi & 4 & 9,09 & 1 & 2,27 & 5 & 11,36 \\
\hline \multicolumn{7}{|c|}{ 3. Pemeriksaan ANC } \\
\hline Memenuhi K4 & 26 & 59,09 & 15 & 34,09 & 41 & 93,18 \\
\hline $\begin{array}{l}\text { Tidak } \\
\text { memenuhi K4 }\end{array}$ & 2 & 4,55 & 1 & 2,27 & 3 & 6,82 \\
\hline
\end{tabular}

\section{Determinan Kejadian Anemia Responden}

Berdasarkan Tabel 4 diketahui dari 44 responden dapat dijelaskan bahwa tingkat konsumsi karbohidrat, protein, lemak dalam 
kategori lebih sebesar 38,64\%; 70,45\% dan $50,00 \%$. Sedangkan, sebagian besar konsumsi zat besi (termasuk tablet Fe) dan zat enhancer Fe dalam kategori defisit sebesar 54,55\% dan $68,18 \%$. Pada pola konsumsi zat inhibitor Fe, sebagian besar ibu hamil tidak pernah mengonsumsi teh, kopi dan kentang sebesar $40,91 \%$; $54,55 \%$ dan 36,36\%, ibu jarang mengonsumsi kacang panjang sebesar $88,64 \%$, dan sering mengonsumsi ketimun sebesar $40,91 \%$.

Tabel 4. Distribusi Frekuensi Determinan Kejadian Anemiapada Ibu Hamil Kurang Energi Kronis di Wilayah Kerja Puskesmas Sumberjambe Tahun 2017

\begin{tabular}{lcccccc}
\multicolumn{1}{c}{ Variabel } & \multicolumn{3}{c}{ Anemia } & \multicolumn{2}{c}{ Tidak } & \multicolumn{2}{c}{ Jumlah } \\
& n & \% & n & \% & n & \% \\
\hline 1. Karbohidrat & & & & & & \\
Defisit Berat & 8 & 18,18 & 2 & 4,55 & 10 & 22,73 \\
Defisit Sedang & 1 & 2,27 & 1 & 2,27 & 2 & 4,55 \\
Defisit Ringan & 2 & 4,55 & 1 & 2,27 & 3 & 6,82 \\
Normal & 7 & 15,91 & 5 & 11,36 & 12 & 27,27 \\
Lebih & 10 & 22,73 & 7 & 15,91 & 17 & 38,64 \\
2. Protein & & & & & & \\
Defisit Berat & 5 & 11,36 & 1 & 2,27 & 6 & 13,64 \\
Defisit Sedang & 1 & 2,27 & 1 & 2,27 & 2 & 4,55 \\
Defist Ringan & 1 & 2,27 & 0 & 0,00 & 1 & 2,27 \\
Normal & 2 & 4,55 & 2 & 4,55 & 4 & 9,09 \\
Lebih & 19 & 43,18 & 12 & 27,27 & 31 & 70,45 \\
3. Lemak & & & & & & \\
Defisit Berat & 11 & 25,00 & 3 & 6,82 & 14 & 31,82 \\
Defisit Sedang & 1 & 2,27 & 0 & 0,00 & 1 & 2,27 \\
Defisit Ringan & 0 & 0,00 & 0 & 0,00 & 0 & 0,00 \\
Normal & 2 & 4,55 & 5 & 11,36 & 7 & 15,91 \\
Lebih & 14 & 31,82 & 8 & 18,18 & 22 & 50,00 \\
4. Fe & & & & & & \\
Defisit Berat & 15 & 34,09 & 9 & 20,45 & 24 & 54,55 \\
Defisit Sedang & 0 & 0,00 & 0 & 0,00 & 0 & 0,00 \\
Defisit Ringan & 0 & 0,00 & 0 & 0,00 & 0 & 0,00 \\
Normal & 3 & 6,82 & 2 & 4,55 & 5 & 11,36 \\
Lebih & 10 & 22,73 & 5 & 11,36 & 15 & 34,09 \\
5.Enhancer: & & & & & & \\
Vitamin C & & & & & & \\
Defisit Berat & 17 & 38,64 & 9 & 20,45 & 26 & 59,09 \\
Defisit Sedang & 1 & 2,27 & 2 & 4,55 & 3 & 6,82 \\
Defisit Ringan & 1 & 2,27 & 0 & 0,00 & 1 & 2,27 \\
Normal & 4 & 9,09 & 3 & 6,82 & 7 & 15,91 \\
Lebih & 5 & 11,36 & 2 & 4,55 & 7 & 15,91 \\
Inhibitor & & & & & & \\
A. Tannin & & & & & & \\
1) Teh & & & & & & \\
Sering & 10 & 22,73 & 4 & 9,09 & 14 & 31,82 \\
Jarang & 7 & 15,91 & 5 & 11,36 & 12 & 27,27 \\
\hline & 11 25,00 & 7 & 15,91 & 18 & 40,91 \\
\hline
\end{tabular}

Tabel 4. Distribusi Frekuensi Determinan Kejadian Anemiapada Ibu Hamil Kurang Energi Kronis di Wilayah Kerja Puskesmas Sumberjambe Tahun 2017 (lanjutan)

\begin{tabular}{lcccccc}
\hline \multicolumn{3}{c}{ Variabel } & \multicolumn{3}{c}{ Status Anemia } & \multicolumn{2}{c}{ Jumlah } \\
& n & \% & n & \% & n & \% \\
\hline 2) Kopi & & & & & & \\
Sering & 9 & 20,45 & 7 & 15,91 & 16 & 36,36 \\
Jarang & 2 & 4,55 & 2 & 4,55 & 4 & 9,09 \\
Tidak pernah & 17 & 38,64 & 7 & 15,91 & 24 & 54,55 \\
B. Asam fitat & & & & & & \\
1) Kc. panjang & & & & & & \\
Sering & 27 & 61,36 & 12 & 27,27 & 39 & 88,64 \\
Jarang & 1 & 2,27 & 4 & 9,09 & 5 & 11,36 \\
Tidak pernah & 0 & 0,00 & 0 & 0,00 & 0 & 0,00 \\
C. Asam oksalat & & & & & & \\
1) Ketimun & & & & & & \\
$\quad$ Sering & 13 & 29,55 & 5 & 11,36 & 18 & 40,91 \\
Jarang & 6 & 13,64 & 9 & 20,45 & 15 & 34,09 \\
Tidak pernah & 9 & 20,45 & 2 & 4,55 & 11 & 25,00 \\
2) Kentang & & & & & & \\
$\quad$ Sering & 12 & 27,27 & 2 & 4,55 & 14 & 31,82 \\
Jarang & 9 & 20,45 & 5 & 11,36 & 14 & 31,82 \\
Tidak pernah & 7 & 15,91 & 9 & 20,45 & 16 & 36,36 \\
\hline
\end{tabular}

\section{PEMBAHASAN}

\section{Status Anemia Gizi Besi Responden}

Hasil penelitian ini menunjukkan bahwa ibu hamil lebih banyak mengalami anemia gizi besi (AGB) karena dipengaruhi adanya malnutrisi atau KEK yang disebabkan oleh pola konsumsi dan absorbsi makanan yang tidak seimbang selama masa kehamilan. Jika ibu selama kehamilan tidak mengonsumsi gizi seimbang, baik zat gizi makro maupun zat gizi mikro maka ibu hamil berisiko mengalami gangguan gizi atau dapat terjadinya KEK yang dapat mengakibatkan AGB.

\section{Karakteristik Responden}

Umur ibu pada saat hamil merupakan salah satu faktor yang menentukan tingkat risiko kehamilan dan persalinan. Rata-rata ibu hamil pada penelitian ini berada pada umur produktif. Anemia gizi besi cenderung terjadi pada wanita usia subur yang berada di kelompok umur produktif karena pada masa ini merupakan periode penting dalam kehidupan wanita, pada umumnya wanita sudah menikah, hamil dan menyusui anak.

Pendidikan adalah proses pertumbuhan, perkembangan, atau perubahan kearah yang 
lebih dewasa dan lebih matang pada diri individu, kelompok dan masyarakat (Notoadmodjo, 2007). Sebagian besar ibu hamil KEK di wilayah kerja Puskesmas Sumberjambe memiliki pendidikan dasar, sedangkan tingkat pendidikan ibu hamil KEK yang cenderung menderita AGB berada pada tingkat pendidikan menengah. Meskipun memiliki pendidikan menengah, kurangnya pemahaman ibu hamil menyebabkan ibu tidak mengetahui cara menyikapi adanya informasi kesehatan, terutama bahaya AGB baginya dan janin yang dikandung.

Pekerjaan adalah aktivitas atau kegiatan yang dilakukan oleh seseorang memperoleh penghasilan (Notoadmodjo, 2007). Sebagian besar ibu hamil KEK di wilayah kerja Puskesmas Sumberjambe tidak bekerja. Banyaknya ibu yang tidak bekerja disebabkan sebagian besar ibu memiliki pendidikan yang dasar sehingga tidak memenuhi syarat pendidikan minimum yang ditetapkan oleh berbagai usaha sektor formal. Sebagian ibu hamil memiliki suami yang bekerja sebagai petani atau buruh tani, sehingga selain sebagai ibu rumah tangga mereka membantu suami bertani di ladang.

Sebagian besar keluarga di wilayah kerja Puskesmas Sumberjambe memiliki pendapatan dibawah Upah Minimum Kabupaten Jember. Hal ini dikarenakan hanya suami saja yang bekerja untuk memenuhi kebutuhan keluargasehari-hari.Terbatasnya pendapatan keluarga membatasi kesanggupan keluarga untuk membeli bahan makanan tinggi sumber zat gizi yang harganya relatif mahal dan akses terhadap pelayanan kesehatan juga kurang.

Pengetahuan atau kognitif merupakan domain yang sangat penting dalam membentuk tindakan seseorang (overt behaviour) (Notoadmodjo, 2007). Sebagian besar ibu hamil KEK di wilayah kerja Puskesmas Sumberjambe memiliki pengetahuan yang cukup. Berdasarkan wawancara pada bidan desa diketahui bahwa ibu hamil yang dating ke posyandu selain memeriksakan kehamilannya juga mendapatkan penyuluhan gizi yang disampaikan oleh bidan desa.

\section{Status Kesehatan Responden}

Paritas mempengaruhi kejadian AGB pada kehamilan, semakin sering seorang wanita hamil dan melahirkan maka risiko mengalami anemia semakin besar karena kehamilan menguras cadangan zat besi dalam tubuh. Sebagian besar ibu hamil KEK di wilayah kerja Puskesmas Sumberjambe memiliki paritas rendah. Hal ini dikarenakan sebagian besar responden mengalami kehamilan anak pertama sehingga paritas 0 . Adapun seorang ibu yang hamil pertama kali memiliki risiko yang tinggi untuk mengalami anemia, karena ibu belum memiliki pengalaman sehingga berdampak pada perilaku yang berkaitan dengan asupan nutrisi.

Salah satu penyebab yang dapat mempercepat terjadinya AGB pada ibu hamil KEK yaitu jarak kelahiran yang pendek. Sebagian besar ibu hamil KEK di wilayah kerja Puskesmas Sumberjambe memiliki jarak kelahiran dengan risiko rendah. Hal ini dikarenakan rata-rata responden hamil anak pertama. Jarak ideal antar kelahiran adalah lebih dari 2 tahun, sehingga dapat memberi kesempatan pada tubuh untuk memenuhi kebutuhan nutrisi dan memperbaiki organorgan reproduksi untuk siap mengandung lagi.

Pemeriksaan ANC yang dilakukan secara teratur dan komprehensif dapat mendeteksi secara dini risiko dan kelainan yang bisa timbul pada masa kehamilan, sehingga risiko dan kelainan tersebut dapat diatasi dengan cepat dan tepat. Sebagian besar ibu hamil KEK di wilayah kerja Puskesmas Sumberjambe memeriksakan kehamilannya secara berkala dan memenuhi K4. Pemeriksaan kehamilan yang dianjurkan pada ibu hamil yaitu melakukan pengawasan antenatal sebanyak 4 kali, yaitu pada setiap trimester, sedangkan trimester terakhir sebanyak dua kali (Manuaba, 2012).

\section{Determinan Kejadian Anemia Responden}

Berdasarkan hasil penelitian di wilayah kerja Puskesmas Sumberjambe, tingkat konsumsi karbohidrat pada sebagian ibu hamil KEK masuk dalam kategori lebih. Karbohidrat yang dikonsumsi berlebih akan mengakibatkan terjadinya konversi hidratarang yang berlebih menjadi lemak sehingga menimbulkan kegemukan, sedangkan asupan karbohidrat yang tidak mencukupi mengakibatkan tidak cukupnya glukosa yang tersedia untuk menghasilkan energi, sehingga lemak digunakan hingga taraf yang melampaui keadaan normal (Beck, 2011).

Tingkat konsumsi protein pada ibu hamil KEK di wilayah kerja Puskesmas Sumberjambe masuk dalam kategori lebih. Sebagian besar ibu hamil mengonsumsi 
protein nabati seperti tempe dan tahu yang merupakan sumber protein nabati yang menyumbangkan kandungan protein cukup besar dan zat gizi. Kebiasaan mengonsumsi lebih banyak protein nabati dibandingkan dengan protein hewani menyebabkan absorbsi zat besi kurang optimal.

Tingkat konsumsi lemak ibu hamil KEK di wilayah kerja Puskesmas Sumberjambe dalam kategori lebih. Ketidakseimbangan antara terjadinya KEK dan AGB pada ibu hamil dengan tingkat konsumsi karbohidrat, protein dan lemak karena kebanyakan ibu hamil KEK mencukupi kebutuhan energinya dengan lebih banyak mengonsumsi salah satu di antara ketiga zat gizi tersebut dibandingkan mengonsumsi ketiganya secara seimbang.

Tingkat konsumsi zat besi pada sebagian besar ibu hamil KEK di wilayah kerja Puskesmas Sumberjambe dalam kategori defisit. Sebagian besar responden kurang mengonsumsi makanan yang mengandung zat besi saat dilakukan recall $2 \times 24$ jam dan tidak mengonsumsi tablet $\mathrm{Fe}$ yang memberikan sumbangan zat besi sebanyak $60 \mathrm{mg} /$ tablet. Kekurangan zat besi pada ibu hamil dapat mengakibatkan AGB yang menyebabkan abortus), kelahiran prematur, inersia uteri, atonia uteri, syok, infeksi baik saat bersalin maupun pasca bersalin, serta anemia yang berat (>4 g/dl) dapat menyebabkan dekompensasi kordis (Saifuddin, 2010).

Vitamin C dalam jumlah yang cukup dapat melawan sebagian faktor-faktor yang dapat menghambat penyerapan zat besi (Almatsier, 2011). Tingkat konsumsi vitamin C pada sebagian besar ibu hamil KEK di wilayah kerja Puskesmas Sumberjambe dalam kategori defisit. Vitamin C dalam makanan yang dikonsumsi berperan dalam meningkatkan penyerapan $\mathrm{Fe}$ dalam tubuh terutama zat besi nonheme sehingga produksi sel darah merah pun akan meningkat seiring dengan peningkatan Fe dalam tubuh.

Tannin merupakan polifenol yang terdapat di dalam teh, kopi dan beberapa jenis sayuran dan buah. Sebagian besar ibu hamil KEK di wilayah kerja Puskesmas Sumberjambe tidak pernah mengonsumsi teh dan kopi. Tannin dapat mengikat mineral dan pada sebagian teh senyawa polifenol berperan sebagai antioksidan ternyata telah mengalami oksidasi, sehingga dapat mengikat mineral seperti Fe, Zn dan Ca sehingga penyerapan zat besi berkurang.
Asam fitat dianggap sebagai antrinutrisi pada bahan pangan. Sebagian besar ibu hamil KEK di wilayah kerja Puskesmas Sumberjambe sering mengonsumsi kacang panjang. Pada kondisi alami, asam fitat akan membentuk ikatan baik dengan mineral bervalensi dua $(\mathrm{Ca}, \mathrm{Mg}, \mathrm{Fe})$, maupun protein menjadi senyawa yang sukar larut. Hal ini menyebabkan mineral dan protein tidak dapat diserap tubuh atau nilai cernanya rendah.

Asam oksalat dalam sayuran dapat menghambat penyerapan zat besi dengan cara mengikat zat besi (Almatsier, 2011). Sebagian besar ibu hamil KEK di wilayah kerja Puskesmas Sumberjambe sering mengonsumsi ketimun dan tidak pernah mengonsumsi kentang. Beberapa sayuran tersebut mempunyai manfaat yang baik bagi tubuh, namun jika dikonsumsi dengan frekuensi yang sering akan menimbulkan dampak bagi tubuh.

\section{KESIMPULAN DAN SARAN}

Kesimpulan dari penelitian ini yaitu hasil penelitian menyatakan bahwa berdasarkan faktor karakteristik, sebagian besar ibu hamil berada pada kelompok umur muda $(<20$ tahun), memiliki tingkat pendidikan dasar, tidak bekerja, pendapatan keluarga dibawah UMK, serta memiliki pengetahuan cukup. Berdasarkan faktor status kesehatannya, sebagian besar ibu hamil terdiri dari paritas rendah, memiliki jarak kelahiran rendah, pemeriksaan kehamilan ANC memenuhi K4. Berdasarkan faktor tingkat konsumsi sebagian besar konsumsi karbohidrat, protein dan lemak dalam kategori lebih. Sedangkan, konsumsi zat besi (termasuk tablet $\mathrm{Fe}$ ) dan zat enhancer $\mathrm{Fe}$ dalam kategori defisit. Pada pola konsumsi zat inhibitor Fe, sebagian besar ibu hamil tidak pernah mengonsumsi teh, kopi, kentang dan sering mengonsumsi kacang panjang dan ketimun. Sebagian besar ibu hamil KEK sebanyak 28 orang mengalami AGB dan 16 orang tidak mengalami AGB.

Saran yang dapat diberikan berdasarkan hasil penelitian ini adalah ibu hamil KEK yang mengalami AGB untuk meningkatkan asupan makanan bergizi, teratur mengonsumsi tablet $\mathrm{Fe}$ dan mengonsuminya bersamaan dengan zat enhancer $\mathrm{Fe}$ dan menghindari zat inhibitor $\mathrm{Fe}$, dan memvariasikan bahan makanan sehingga kebutuhan terpenuhi dengan baik.

Dinas Kesehatan diharapkan proaktif meningkatkan program perbaikan gizi dan pengawasan terhadap PMT maupun tablet Fe 
bagi ibu hamil KEK yang mengalami AGB dan meningkatkan kerjasama dengan lintas sektoral yaitu Departemen Agama untuk menambahkan pengetahuan dalam pelaksanaan pernikahan agar menunda kehamilan sampai batas ideal. Puskesmas perlu bekerjasama dengan KUA dengan merujuk calon pengantin mendapatkan penyuluhan kesehatan, memonitoring dan evaluasi kartu kontrol minum tablet $\mathrm{Fe}$, memvalidasi setiap bulan untuk mengontrol data ibu hamil yang berisiko atau tidak berisiko, meningkatkan pengetahuan bidan puskesmas dengan pelatihan, meningkatkan kualitas pemeriksaan ANC, memeriksakan kadar $\mathrm{Hb}$ pada ibu hamil, penambahan tablet Fe 2 tablet/ hari. Peneliti lain diharapkan dapat melakukan penelitian lanjut tentang determinan lain yang dapat mempengaruhi terjadinya AGB pada ibu hamil KEK, meliputi: infeksi, penyakit yang berhubungan dengan kehamilan, lingkungan serta faktorfaktor lainnya agar informasi yang diperoleh dapat saling melengkapi.

\section{DAFTAR RUJUKAN}

1] Almatsier, S. (2011) Prinsip Dasar Ilmu Gizi. Jakarta: PT. Gramedia Pustaka Utama.

2] Beck, M. E. (2011) Ilmu Gizi dan Diet: Hubungannya Dengan Penyakit-Penyakit Untuk Perawat dan Dokter. Yogyakarta: Andi Yogyakarta.

3] Centers for Disease Control and Prevention. (2005) Worldwide Prevalence of Anaemia 1993-2005 (WHO Global Database on Anaemia). Geneva, Switzerland: World Health Organization.
4] Citrakesumasari. (2012) Anemia Gizi, Masalah, Dan Pencegahannya. Yogyakarta: Kalika.

5] Departemen Kesehatan RI. (2007) Riset Kesehatan Dasar 2007. Jakarta: Badan Penelitian dan Pengembangan Kesehatan.

6] Departemen Kesehatan RI. (2009) Profil Kesehatan Indonesia Tahun 2008. Jakarta: Depkes RI.

7] Kementerian Kesehatan RI. (2013) Riset Kesehatan Dasar 2013. Jakarta: Badan Penelitian dan Pengembangan Kesehatan.

8] Manuaba, I. B. G. (2012) Ilmu Kebidanan, Penyakit Kandungan dan Keluarga Berencana Untuk Pendidikan Bidan. Jakarta: EGC.

9] Maulana, M. (2007) What A Woman Wants: Cara Cerdas Merencanakan dan Menjalani Kehamilan. Yogyakarta: Kata Hati.

10] Notoatmodjo, S. (2007) Promosi Kesehatan dan Ilmu Perilaku. Jakarta: Rineka Cipta.

11] Rochjati, P. (2013) Skrining Antenatal pada Ibu Hamil. Surabaya: FK Universitas Airlangga.

12] Saifuddin, A. B. (2010) Buku Panduan Praktis Pelayanan Kesehatan Maternal dan Neonatal. Jakarta: Yayasan Bina Pustaka Sarwono Prawirohardjo.

13] Soekirman. (2004) Ilmu Gizi dan Aplikasinya Untuk Keluarga dan Masyarakat. Jakarta: Direktorat Jenderal Pendidikan Tinggi Departemen Pendidikan Nasional. 